PART THREE

PERSONAL MEMORY 
Susan Broomhall - 9789004261259

Downloaded from Brill.com04/26/2023 10:42:47AM via free access 


\title{
DISTURBING MEMORIES. NARRATING EXPERIENCES AND EMOTIONS OF DISTRESSING EVENTS IN THE FRENCH WARS OF RELIGION*
}

\author{
Susan Broomhall
}

This essay asks how people memorialised distressing events in sixteenthcentury France. Exactly what constituted troubling memories for sixteenth-century people and how did they articulate their feelings about these events? Such questions have until now been mostly asked of literary and visual genres in studies of sixteenth-century violence. ${ }^{1}$ In a recent collection of essays studying trauma in Francophone literary traditions, for example, authors examined how genre inflected traumatic narratability, analysing 'the challenge of narrating trauma and the ways in which authors have made use of traditional or reconfigured generic forms in their attempts to translate traumatic experience'. ${ }^{2}$ However, if we hope to expand the range of evidence available to study memories of troubled experiences in the often extreme violence of that century, we must attend to the contexts of production of varied genres and the possibilities that they allowed for very different expressions of disturbing memories. For

\footnotetext{
* I am grateful for the insightful feedback of Erika Kuijpers. Early research for this essay was made possible through an Australian Research Council Discovery Grant.

${ }^{1}$ See, for example, Kathleen Perry Long, 'The representation of violence in the works of Theodore Agrippa d'Aubigné', in Timothy Murray and Alan K. Smith (eds.), Repossessions. Psychoanalysis and the phantasms of early modern culture (Minneapolis: University of Minnesota Press, 1998), 142-167; François Rigolot, 'French renaissance writers and the wars of religion. Ronsard, Montaigne and d'Aubigné', French Literature Series 25 (1998), 1-23; Philip Benedict, Lawrence M. Bryant and Kristen B. Neuschel, 'Graphic history. What readers knew and were taught in the Quarante tableaux of Perrissin and Tortorel', French Historical Studies 28 (2005), 175-229; Zahi Zalloua, 'From Le Printemps to Les Tragiques. Trauma, self-narrative and the metamorphosis of poetic identity in Agrippa d'Aubigné', special issue: representations of trauma in French and Francophone literature, Dalhousie French Studies 81 (2007), 29-39; Kathleen Perry Long, '“Child in the water". The spectacle of violence in Théodore Agrippa d'Aubigné', Dalhousie French Studies 81 (2007), 155-165. One exception is Mark Greengrass, 'Hidden transcripts. Secret histories and personal testimonies of religious violence in the French wars of religion', in Mark Levene and Penny Roberts (eds.), The massacre in history (New York and Oxford: Berghahn, 1999), 69-88.

2 Nicole Simek, 'Introduction', special issue. Representations of trauma in French and Francophone literature, Dalhousie French Studies 81 (2007), 1-3, there 3.
} 
personal narratives do exist that were not written by scholars or poets, and they were often presented to their readers for many different purposes. ${ }^{3}$ Narrative context (in its functions, structure, and goals) as well as the genres that these necessitated shaped the kinds of episodes of violence and distress that could be remembered and the way these memories and the emotions they generated could be expressed.

Despite repeated official injunctions to oubliance, as Kathleen Long has argued, the period during and following the wars of religion in France saw an explosion of literary, artistic and historical works which attempted to make sense of the period's violent events. ${ }^{4}$ At some level, all written accounts are acts of memorialisation, where decisions are made about what to include and what to leave out. Indeed, Susan J. Brison has critiqued the tendency in trauma analyses to distinguish between

traumatic memories (viewed as bodily, fragmented, sensory, intrusive, recurrent, uncontrollable) and narrative memories (viewed as linguistic, more coherent, more under control). Traumatic memory, like narrative memory, is articulated, selective, even malleable, in spite of the fact that the framing of such memory may not be under the survivor's conscious control. ${ }^{5}$

By their nature, narratives 'have an orientation, a temporal sequence of actions, a complication, an evaluation, and a resolution', ${ }^{6}$ although these facets may be more or less explicit in each text. With this in mind, I have tried to scan widely across different document types to be alert to records of disturbing memories and to see what opportunities particular sources provided for different narratives and kinds of violence and sentiments to be recalled and recorded. I thus approach the narratives examined here as not simply presented in, but also as produced through, their particular form. There were also different audiences, times, and socio-historical contexts that allowed for different stories to be heard by particular

3 On the purposes of such narratives, see Susan Broomhall, 'Reasons and identities to remember. Composing personal accounts of religious violence in sixteenth-century France', French History 27 (2013), 1-20.

4 Long, '"Child in the water"', 160.

5 Susan J. Brison, Aftermath. Violence and the re-making of a self (Princeton: Princeton University Press, 2002), 31.

${ }^{6}$ Kathleen Slobin, 'Repairing broken rules. Care-seeking narratives for menstrual problems in rural Mali', Medical Anthropology Quarterly 12.3 (1998), 363-383, there 367. Slobin borrows here from the work of William Labov, 'Speech actions and reactions in personal narrative', in Deborah Tannen (ed.), Analyzing discourse. Text and talk (Washington: Georgetown University Press, 1982), 219-247, and William Labov and Joshua Waletsky, 'Narrative analysis, oral versions of personal experience', in June Helm (ed.), Essays on the verbal and visual arts (Seattle: University of Washington Press, 1967), 12-44. 
narrators, ${ }^{7}$ for the nature of distress, emotional expression, and access to written memory-making were all socially coded and determined. ${ }^{8}$ Constructions and presentations of identity permitted certain narratives to be expressed and shaped how they were articulated and to whom as well as in what contexts and genres they were produced, and for what purposes.

When analysing how feelings about violence were narrated, it is impossible to distinguish those experienced at the time from those remembered or perhaps created in the act of later reflection. While the rhetoric, techniques and omissions of mémoires as a genre have received detailed attention from historians and literary scholars, ${ }^{9}$ scholarly investigation of the emotional articulation of violence in such records is more limited. For the sixteenth century, analyses have focussed particularly on confessional distinctions (and limitations) regarding affective expression. Costas Gaganakis, for example, has argued that Calvinism's 'strict emotional regime ... sought to impose strong emotional management tools, based on the bipolar construction of sin and redemption, at the expense of allowing scope for self-exploration and navigation on the part of members of the community'. ${ }^{10}$ Others have considered the possibility of repression or incapacity to articulate the violent events experienced. Mark Greengrass

7 As Diane Bjorklund argues, autobiographical narratives are produced with assumptions about their readerships which affect how and which events are recounted and the self-appropriate to that audience. See Diane Bjorklund, Interpreting the self. Two hundred years of American autobiography (Chicago: The University of Chicago Press, 1998), 10, 17.

8 In this respect, some of the recent psychological literature that examines gender analysis of distress is rather unhelpful because the social coding of modern gender emotive expression does not match that of early modern records. Useful studies, however, for considering gender differences in the production of trauma memory (although the outcomes are clearly different from those studied here) have been Myrna Goldberg, 'Memoirs of Auschwitz survivors. The burden of gender', in Carol Rittner and John K. Roth (eds.), Different voices. Women and the Holocaust (New York: Paragon House, 1993), 327-339 and Sara Reva Horowitz, 'Women in Holocaust literature. Engendering trauma memory', in Dalia Ofer and Lenore J. Weitzman (eds.) Women in the Holocaust (New Haven: Yale University Press, 1998), 364-377.

9 See, for example, the significant Francophone work in this area. Noémi Hepp and Jacques Hennequin (eds.), Les valeurs chez les mémorialistes français du XVIIe siècle avant la Fronde (Paris: Klincksieck, 1979); Madeleine Bertaud and André Labertit (eds.), De l'Estoile à Saint-Simon. Recherche sur la culture des mémorialistes au temps des trois premiers rois Bourbon (Paris: Klincksieck, 1993); Madeleine Bertaud and François-Xavier Cuche (eds.), Le genre des mémoires. Essai de définition (Paris: Klincksieck, 1995); Nadine Kuperty-Tsur, Se dire à la renaissance. Les mémoires au XVI ${ }^{e}$ siècle (Paris: J. Vrin, 1997); Jacques Berchtold and Marie-Madeleine Fragonard (eds.), La mémoire des guerres de religion. La concurrence des genres historiques XVIe-XVIII ${ }^{e}$ siècles (Genève: Droz, 2007).

10 Costas Gaganakis, 'Stairway to heaven. Calvinist grief and redemption in the French Wars of Religion', Historein 8 (2008), 105. 
suggests, for instance, that the absence of elaborated affective expression by eye-witness narrators of the Saint Bartholomew's Massacre might result from such eye-witnesses having 'no means of explaining to others, in language which could possibly convey it, the full emotional intensity of what they had experienced'.11

Do such findings take sufficient account, however, of contemporary forms of affective expression and conceptualisation? In the sections to follow I explore different kinds of accounts presenting disturbing memories of the sixteenth century's violent events. In doing so, I ask: can we identify words, phrasing, and structures that reflect early modern narrators' methods of engaging with those memories? How did emotions function to enable articulation of a distressing event, and where and when was emotional vocabulary employed in its recall? Who could use certain emotional descriptions and vocabularies in order to express particular kinds of feelings about violence that narrators remembered experiencing?

\section{Affective Memories}

Distress about the religious violence and upheavals was memorialised in personal accounts by many narrators for a wide variety of audiences and contexts, as we shall see. For some, explicit emotional language was critical to narrating disturbing events. This appears particularly common among Catholic religious, whose chronicles documented in dramatic and highly-charged emotive language the destruction of religious sites and objects, the dispersal of the community to safer properties, and the risk of sexual violence, as well as troop movements, battles and victories of the faithful. ${ }^{12}$

However, the same mode of expression can also be located in accounts produced by Catholic lay faithful. The chronicle of Etienne Médicis, a merchant and bourgeois citizen of Le Puy, purported to compile a history of his town for the edification of its magistrates, consuls and citizens. While a series of the events he detailed preceded his birth, the latter portion of the text recorded his eye-witness experiences of Huguenot attacks on the

11 Greengrass, 'Hidden transcripts', 8o.

12 See discussion of these in Broomhall, 'Reasons and identities to remember'; Susan Broomhall, 'Disorder in the natural world. The perspectives of a sixteenth-century provincial convent', in Jennifer Spinks and Dagmar Eichberger (eds.) Religion, the supernatural and visual culture in early modern Europe (Leiden: Brill, 2014, forthcoming). 
town. Médicis built up a catalogue of violence to sacred religious statues and images: how Huguenots had broken the arms and legs off crucifixes in the cemetery of Broueil and how in 1554 they had in the dead of night destroyed the image of St Martin from the conventual church of Saint Laurens. On 10 March 1561, some people 'put their polluted hands quite viciously on the image of the glorious Mary Magdalene'.13 Then Médicis described how Huguenots in Le Puy had desecrated the holy and miraculous image of Nôtre-Dame in word and deed:

calling her idol, chunk of wood, blackened thing and her images made on paper arse-wipes, and they were said to put the good Lady's rosary on their dogs, and other varied and vile, outrageous, disgraceful, atrocious insults that they proffered against this holy image [...] I am sad and horrified to write them down! ${ }^{14}$

This violence was not (as yet) violence to Le Puy's population but damage to long-held rituals and customs of the town. In the following year, Médicis would report how, for the procession of May 1562, the bishop had to be accompanied by a large number of arquebusiers: 'a monstruous and pitiful thing to see'.15 These observations were filled, for Médicis, with grief, sadness and sorrow. The damage to cherished icons was, for Catholic faithful, 'a difficult sight for the people to see'. ${ }^{16}$ As Médicis neared the end of his chronicle, he feared for the future: 'things have fallen into such disorder that, if God does not extend us his grace, the Church and the temporal world, all will undoubtedly fall into extreme desolation'. ${ }^{17}$

This affective language was shared by lay and religious Catholics alike, in an emotional regime that was also that of the anticipated readership of such works. One might assume that these readers would already be inclined to sympathise with losses suffered in violent attacks, yet this sympathy did not alter the strong emotional language of such narratives. Instead, these narrators shared an affective rhetoric of suffering and lament for their individual losses, which marked and bound them as members of their faith. Indeed, ostentatious grief set such narratives apart from the Calvinist model of controlled emotional expression and could

13 Augustin Chassaing (ed.), Le livre de Podio, ou chroniques d'Etienne Médicis, 2 vols., (Le Puy-en-Velay: M.-P. Marchessou, 1869), vol. 1, 511-512.

14 Ibid., 512.

15 Ibid., 528 .

16 Ibid., 504 .

17 Ibid., 504. 
thus be read as a particular act of devotion. ${ }^{18}$ For these narrators, explicit emotional terms enabled and articulated grief, sorrow and loss, but this was not the case for all those who recounted distressing experiences.

\section{Indirect Autobiography. Emotions at a Distance}

For another group of authors, violence was narrated within mémoires that documented the participation of elite men in the political and military actions of their day. ${ }^{19}$ A series of such mémoires eschewed first-person narrative, adopting an authorial voice in either the second, or more commonly, third person. Simone Bertière has suggested that this style distinguished such individuals as aristocrats, ostensibly with secretaries to undertake the business of writing their lives for posterity: 'To great lords the sword, to their subordinates the pen'. ${ }^{20}$ The impersonal voice of the fictive narrator, she observes, suited facts and events but was less appropriate for passages of reflection, anecdote or piquant details. ${ }^{21}$ At first glance, such accounts would seem an unlikely source for feelings about the violence which these authors had experienced first-hand.

Yet some authors did describe their emotions upon witnessing the violence of such events as the Saint Bartholomew's Massacre. Interestingly, accounts by both Catholic and Calvinist male narrators emphasised the need to repress and control the emotions they felt at the time. JacquesAuguste de Thou, for example, remembered the horrific sight of mutilated bodies in the street on 'this terrible day'.

He could not look without horror at the bodies of Jérôme Groslot, bailli of Orléans, and of Calixte Garrault, that they dragged to the river by the closest street. He was obliged to witness these horrible things without daring to shed a tear, he whose natural tenderness did not permit him to see the death of an innocent animal without emotion. The pain that this caused him obliged him to go out no more, for fear of encountering similar sights. ${ }^{22}$

18 See also chapter 14 by Andreas Bähr.

19 Or sometimes in defence of their personal character, distinct from the political events in which they were involved.

20 Simone Bertière, 'Le recul de quelques mémorialistes devant l'usage de la première personne. Réalité de la rédaction et artifices de l'expression', in Hepp and Hennequin (eds.), Les valeurs chez les mémorialistes français, 65-88, there 66-67.

21 Ibid., 69.

22 'Mémoires de Jacques-Auguste de Thou, depuis 1553 jusqu'en 16o1', ed. Claude-Bernard Petitot, in Collection des mémoires rélatifs à l'histoire de France, Series I, $5^{2}$ vols. (Paris: Foucault, 1819-29), vol. 37 (1823), 232. 
De Thou's muted, if not openly jubilant, response to the death of confessional 'others' was necessary at the time, marking out his membership among the Catholic faithful. However, his mémoires revealed a secondary emotional reaction, whether truly felt at the time or developed in retrospect: one of horror of violent cruelty and indignity to the corpses of fellow men.

Calvinist Jacques Nompar de Caumont provided a similar third-person narration of his experiences during the massacre in Paris. His mémoires provided a detailed account of seeing his father and elder brother killed before his eyes. ${ }^{23}$ Caumont was with them both when they were discovered in hiding and pulled onto the streets, taken to the rue des PetitsChamps where soldiers attacked the group, fatally stabbing his father and elder brother. Jacques, covered in blood but unhurt, fell with them, lying motionless in the street as they were stripped of their goods and clothing. There he remained, naked, for hours amongst the dying and dead bodies of his family, a time he recalled as one of deep emotional anguish:

If his body had not been hit, his mind was by contrast cruelly agitated, for he heard his father had remained a long time dying and had heard him sob several times. What anguish and what perplexity to find himself between a father and brother cruelly killed and whose sobs were like stabs of a dagger that pierced his heart! ${ }^{24}$

This scene remained an unquestionably emotional memory which Caumont - at a distance of many years — detailed over several pages of his work, recording the last words and actions of his father and brother as well as those of their tormenters and killers.

Neither author dwelt at length upon his evidently strong feelings about what he witnessed, but neither did he repress the emotions that these events had generated for him at the time and since. It is indeed possible that the device of the fictive narrator may have enabled such authors to articulate feelings which were more difficult to express in a first-person authorial voice. Memories of violence and emotion narrated in indirect autobiographies characterised their authors not as Catholic or Calvinist but rather as learned and aristocratic men of the political and military elite.

23 Mémoires authentiques de Jacques Nompar de Caumont, duc de La Force, ed. Le Marquis de La Grange, 4 vols. (Paris: Charpentier, 1843). Also discussed by Greengrass, 'Hidden transcripts', 78.

24 Mémoires authentiques de Jacques Nompar de Caumont, vol. 1, 18. 


\section{Violence Seen and Heard. Displaced Emotions}

For some narrators, their own feelings in times of violence were not foregrounded in their memories of fighting and violence. Instead, their narratives emphasised how they had heard violent episodes and observed the emotions of others in these acts. ${ }^{25}$

Charlotte Arbaleste de la Borde and her second husband Philippe Duplessis-Mornay were leading Calvinist political advocates. ${ }^{26}$ In 1584 Arbaleste began to write a memoir of her husband as an exemplary life for her son, to which she continued adding until her son's death in $1605 .{ }^{27}$ The memoir concentrated largely on public and historical concerns and in particular on Duplessis-Mornay's military, diplomatic, and political accomplishments. Yet her memories, some of highly distressing events, formed an additional second narrative throughout the text. Arbaleste recounted both her own and her future husband's escape from Paris during the 1572 massacre, hiding in Paris for days, moving from house to house as the trouble spread, before she was finally able to flee the city. Interestingly, how she felt about these events was addressed indirectly; what Arbaleste described were the emotions of those around her-her kitchen maid who first told her the news was 'greatly frightened', while in the street, Arbaleste could see 'everything in such a commotion'. Later, from one hiding place in an attic, she recalled hearing the 'strange cries of men, women and children that they massacred in the streets'. ${ }^{28}$ Sound was a sense that could not be shut out from the mind.

Moreover, Arbaleste allowed others to assess her own emotional state in her text, reporting how the two soldiers who stopped her as she tried to escape the city in a boat suspected her of being a Huguenot because

25 Greengrass ('Hidden transcripts', 76) also notes this feature in the mémoires of Maximilian de Béthune. Attention to date has generally been given to visualising distress and its impact on viewers and readers in printed and literary illustrations of violence. Long, 'The Representation of Violence'; Benedict, Bryant, and Neuschel, 'Graphic history'; Philip Benedict, Graphic history. The wars, massacres and troubles of Tortorel and Perrissin (Geneva: Droz, 2007).

26 See also Catharine Randall, 'Shouting down Abraham. How sixteenth-century Huguenot women found their voice', Renaissance Quarterly 5o (1997), 411-442. See Susan Broomhall and Colette H. Winn, 'La représentation de soi dans les mémoires féminins du début de l'époque moderne', Tangence 78 (2005), 11-35.

27 Susan Broomhall and Colette H. Winn, 'Femme, écriture, foi. Les mémoires de Madame Duplessis-Mornay', Albineana 18 (2007), 587-604; and Les Mémoires de Madame de Mornay, ed. Nadine Kuperty-Tsur (Paris: Honoré Champion, 2010).

28 Ibid., 108. 
she appeared so frightened she could hardly speak. ${ }^{29}$ The emotions that Arbaleste expressed in such moments of violence were mostly ones she attached to those around her, rather than to herself. This approach set an affective tone - of fear and terror - for her own experiences, but Arbaleste did not speak at length of her feelings about them. Such an account (like that of Médicis above) reminds us that explicit emotional language was by no means the exclusive preserve of women but perhaps more closely linked to expressions of faith.

Indeed, on the rare occasion when Arbaleste chose to remember her own emotions in her own words, it was rhetorically purposeful. She remembered experiencing one moment of absolute fear for her daughter in which she felt 'such perplexity and almost despair' that she nearly decided to let herself fall to her death rather than place herself in the hands of the enemy or see her own daughter slaughtered. ${ }^{30}$ This however was a self-criticism the recall of which had a pedagogical intent; despair was a sin. Arbaleste had almost, momentarily, lost faith in God's plan for her, whatever it might be.

\section{Detailing Violence. Affective Values}

As with the accounts above, many narratives of violent events described experiences and destruction in precise detail. Some recounted stories of violent destruction to bodies and properties in the hopes of financial compensation or justice for their losses. ${ }^{31}$ These details implied rather than rendered explicit affective states. In such accounts, affective intensity was rendered in at least two ways: through detailed and cumulative descriptions of the loss, not of people, but of things, and through the careful elaboration of the high financial value of the things that had been destroyed by violence.

After religious violence, convent communities were among those which resorted to legal intervention to secure restitution of their goods. These

29 Ibid., 109 .

30 Ibid., 109 .

31 Penny Roberts has observed that Protestant noblewomen and urban widows could petition successfully on their own behalf. These requests, she argues, were sometimes easier to respond to than those of a whole community. Roberts, Huguenot petitioning during the wars of religion', in Raymond A. Mentzer and Andrew Spicer (eds.), Society and culture in the Huguenot world, 1559-1685, (Cambridge: Cambridge University Press, 2002), 74-75. 
claims were made in terms that emphasised the value of the goods and their meaning to their communities, but grief at their loss and distress at the treatment of sacred objects and spaces in the hands of non-believers were implied rather than foregrounded. After the 1562 religious violence in Lyon, the Benedictine community of Saint-Pierre-des-Nonnains recounted how the community had incurred 'great and inestimable losses, as much of sacred as of profane goods and movable as well as immovable, by the ruin and demolition of their churches and houses done by those who call themselves of the reformed church'. ${ }^{32}$ The sisters particularly lamented the role played by Claude Gosset who had been installed by the Huguenots in the complex with his wife and family and who had 'stolen, pillaged and removed the most beautiful and precious of their sacred and profane goods' ${ }^{33}$ These and other grievances, including the destruction of a wall so that their site communicated directly with the street and the building of a Huguenot temple on one of their lands close by, had tainted the sacred space of their convent site. ${ }^{34}$ Their memories and ongoing experiences of violence and loss spoke of the physical, spiritual and emotional damage of the 'greatly inconvenienced' nuns, but the legal context in which their narrative was presented shifted the focus to precise values and itemised lists, rather than feelings. This approach, they felt, was most likely to achieve what they needed: repairs to their properties and the return of the goods that had been stolen.

For another narrator, it was the detailed and cumulative experience of slow starvation among the Parisian population during the siege of 1590 which stood for the horrors of famine and war. In that year, the staunchly Catholic city was subjected to a four-month siege by Henry of Navarre's forces. Surrounding towns had been cleared by Henry's troops, increasing the population of Paris with few resources to sustain them. Filippo Pigafetta, a zealous Catholic in the employ of the papal legate and eyewitness to the siege, recalled in gruesome and precise detail the depths to which the city's living conditions sunk but also carefully recorded the measures that the city governors took to alleviate the suffering and to spread meagre resources as far as they could. As stocks dwindled, the poor were provided a broth of water through which oat flour had been

\footnotetext{
32 Archives départementales du Rhone, $27 \mathrm{H}_{5} 6$.

33 Ibid.

34 Ibid.
} 
strained with a pinch of salt. ${ }^{35}$ Pigafetta recounted that bread concoctions were carefully measured and made with nut meal, then candle fat, any non-poisonous herbs to be found, and finally were rumoured to be composed of powdered animal bones. Vine leaves still left in the city's gardens were consumed and all the city's horses, donkeys and mules were used as meat while others ate the city's remaining dogs, cats, rats and mice seasoned with vinegar and herbs, and boiled the animals' skins. ${ }^{36}$ Pigafetta estimated that 5000 had died in the siege, not counting infants; other chroniclers suggested that the deaths numbered between 12,000 and 30,000. ${ }^{37}$ This account recorded the full grisly misery of famine for a Catholic Italian audience - the memories of this distressing event were articulated through quantitative data: numbers dead, resources used, and alms distributed. It teased out in fine detail the suffering especially of the poor Catholic faithful of the city at the hands of 'the Navarrois' (later Henry IV) but emphasised that they accepted the torture of hunger for their faith.

\section{In the Margins. Emotions at the Edge}

For Arbaleste, a large digression to recount her own experience of the Saint Bartholomew's Massacre is suggestive of the event's significance in her identity as a Calvinist survivor. ${ }^{38}$ For others too, digressions only marginally related to the purpose of a narrative could reflect the importance of disturbing memories that needed to be told. Rarely did these narratives extend beyond the factual and financial, but their very existence in accounts designed for other purposes is suggestive of their strong affective meaning for individuals.

The 'articles de souvenance' recorded by Jean Robert Le Jeune and his two sons, both named François, from the town of Couchey in the Coted'Or, cover the period from 1573 to 1668 . The events they listed for memorialisation included unusual climate phenomena and astrological signs, and their repercussions for the price of wine or grain. Theirs was not an

35 'Histoire du siège de Paris sous Henri IV en 1590, d'après un manuscrit nouvellement découvert', ed. A. Dufour, Mémoires de la Société de l'Histoire de Paris et de l'Ile-de-France 7 (1880), 206.

36 Ibid., 216-217.

37 Ibid., 77.

38 See, similarly, the account of Renée Burlamacchi in Les femmes et l'histoire familiale (XVI ${ }^{e}-X V I I^{e}$ siècle). Renée Burlamacchi, descrittione della vita e Morte del Signor Michele Burlamachi (1623); Jeanne du Laurens, genealogie de Messieurs du Laurens (1631), eds. Susan Broomhall and Colette H. Winn (Paris: Honoré Champion, 2008). 
account of the elite or of urban citizens but of peasants interested in rural life and events which had a particular bearing on agriculture. Among these events was the destruction caused by Calvinist attacks in their region, such as in 1569, when 'the Huguenots came into this region of Dijon where they did great damage to the poor people and burned houses in several villages, and this was in the month of May $1569{ }^{\prime} \cdot{ }^{39}$ Likewise, in 1576:

the $15^{\text {th }}$ of the month of January, the huguenots came into the region where they carried out great destruction, and came to fight at Nuys where they remained six or seven days, and they came inside and killed the people such as the wine growers and tradespeople, and held the richest people for ransom, and set fire to the town which they left half burned down, and burned many houses and villages that they passed. ${ }^{40}$

These were not entries which dwelt on the emotional impact of these events for those who experienced them, but their very recall in texts speaks to their meaning as the key events in a lifetime that deserved to be recorded for future generations.

Other memories of distress found voice in records that seemed primarily concerned with documenting professional status and achievement. This was the case for Louise Bourgeois who, in the second volume of her published text on midwifery Observations diverses (1617), reflected on her painful memories of living in the suburbs of Paris during the 1590 siege as part of an explanation for why she, the wife of a professional surgeon, had become a midwife. She recalled how her family had been living in SaintGermain when her neighbour had word about the impending approach of soldiers from her husband, who advised his wife to retire with their goods within the walls of Paris. Bourgeois, whose husband was away with the army, did likewise, along with her mother and three children, leaving their properties in the hands of an elderly woman. 'We took only a little furniture with us, because it was hard to get through the Saint-Germain gate without great difficulty'. She described how the King's troops, then the Lasquenets, destroyed the houses her father had built less than five years previously, along with her own financial security and social status:

That night, the suburbs were taken, and all of the best things were pillaged. When the King's men were leaving the suburbs, the city sent out a garrison

39 Deux livres de raison Bourguignons. Le livre de Dominique de Cuny. Chronique dijonnaise du temps de la Ligue, et le livre de la famille Robert. Notes sur le village de Couchey, ed. C. Oursel (Dijon: Libraire J. Nourry, 1908), 108.

40 Ibid., 109. 
of lance-knights, who reduced everything to rubble. Not a stick of wood remained, although most cellars had been full of them. When the lanceknights had left, fifteen thousand livres' worth of houses were destroyed; my father had had them built on the trench at the Bussy Gate, and they had been there for only five years. ${ }^{41}$

Bourgeois then recounted how her family was forced to sell the goods piece by piece to maintain themselves in the city, 'We had no possessions except what little we had brought with us, which we lived off of by selling it day by day, bit by bit... I endured the entire duration of the troubles in this way, until the last month or so'. It was after the family returned from Tours, with a pressing need to generate some revenue, that she was convinced by her own midwife to begin training towards that profession. ${ }^{42}$ Bourgeois' extended discussion of the episode and the details regarding the devastation of the family heritage seem to bear witness to its deep significance for her (echoing the memories and narratives of the paupers discussed above). Her gripping narrative employed a rich vocabulary that made clear her feelings of loss and itemised it in financial terms. However it was also critical to her future professional choices and appeared as such in her chapter entitled: 'How I learned the art of midwifery'.

Such added information highlights how some generic contexts could allow distressing memories to be heard and suggests that authors used their narratives to make sense of past and present identities that were the consequence of traumatic events.

\section{Conclusions}

Attempts to record distressing and violent experiences can be found in a wide range of documents. Authors were often writing at a distance of many years after these events, yet their accounts were no less detailed, no less able to supply precise conversations, names, voices and experiences about what had befallen them or those people and objects that they cherished. Clearly differing contexts and genres shaped their opportunity for expression, the narrative which the memory could participate in, and the kinds of identities that could be associated with it. In turn, sense of

41 Louise Bourgeois, Diverse observations (Paris, 1626), ed. Alison Klairmont Lingo, transl. Stephanie O'Hara, (Toronto: Centre for Reformation and Renaissance Studies Publications, forthcoming).

42 Ibid. 
self shaped where and how people might express distressing events. Many had memories of the violence of the sixteenth century, but few had a wide range of opportunities for recording their specific experiences.

With these provisos, violent events that were deemed worthy of record ranged from murder, attempted rape, and massacres to witnessing the desecration of religious objects in word or deed. Penny Roberts has observed that endemic and continual forms of violence were present in everyday society, arguing that Huguenots suffered intimidation and verbal abuse as well as physical violence. As she points out, it must have been difficult for those living through such situations to know whether this was the limit of their harassment or whether persecution might escalate into something far worse. ${ }^{43}$ Many memories of experiences during the violent wars of religion suggested just such a climate of fear (their own and that of those around them) but also a need to control the expression and visibility of feelings during moments of crisis, for practical reasons as well as in keeping with spiritual beliefs.

On the whole, distressing events were not usually articulated through explicitly emotional vocabulary. Yet narrators negotiated ways within their genres and contexts to document violent experiences that they found disturbing, painful, sad and frightening. Some recollections were visualised, while others remembered cries, speeches and sounds that they could not shut out-experiences that authors felt needed to be heard and seen by their readers. Others found expression of their experiences through itemising things lost or emphasising their financial value. A few ascribed emotions to those around them, suggesting how others felt in such circumstances in ways which implied, but eschewed focus on, their own affective states.

These techniques of emotional expression were consistent with the affective language of their era, gender, status, learning and faith. Scholars of emotion have debated whether texts which do not manifestly speak of feelings should be included for analysis in studies of emotion; but for non-literary narratives of distressing events, this may well be the majority (depending on how manifest expression of feeling is determined). ${ }^{44}$ Yet,

43 Penny Roberts, 'Peace, ritual, and sexual violence during the Religious Wars', in Graeme Murdock, Penny Roberts and Andrew Spicer (eds), Ritual and Violence. Natalie Zemon Davis and Early Modern France, Past and Present Supplements 7 (Oxford; Oxford University Press, 2012), 75-99, there 75-76.

44 Benno Gammerl, 'Emotional styles-communities and spaces' H-Soz-u-Kult. Consulted on 16 September, 2010, from http://hsozkult.geschichte.hu-berlin.de/tagungsberichte/ id $=3275$. 
although recognisable and certainly lengthy affective content may seem less visible to modern readers, emotions were at the very heart of such accounts and of the wars of religion themselves. These evocations of distress experienced, seen, heard and compiled may have been tragic and painful for their authors, but, as we have seen, their modes of expression were often ways to emphasise faith or confessional politics. Moreover, for both sides, these disturbing experiences served a key purpose: they were testament to the glory of suffering for Christ or evidence of His mercy. 